\title{
Intravenous Cysteamine Therapy for Nephropathic Cystinosis
}

\author{
WILLIAM A. GAHL, JULIE INGELFINGER, PARVATHI MOHAN, ISA BERNARDINI, PAUL E. \\ HYMAN, AND ALBERT TANGERMAN
}

\begin{abstract}
Section on Human Biochemical Genetics, National Institute of Child Health and Human Development, National Institutes of Health, Bethesda, Maryland 20892-1830 [W.A.G., I.B.], Department of Nephrology, Massachusetts General Hospital, Boston, Massachusetts 02115 [J.I.], Division of Gastroenterology and Nutrition, Children's National Medical Center, Washington, D.C. 20010 -2970 [P.M.], Department of Pediatric Gastroenterology, Children's Hospital of Orange County, Orange, California 92668 [P.E.H.], and Division of Gastrointestinal and Liver Diseases, University Hospital Nijmegen, Nijmegen, The Netherlands [A.T.]
\end{abstract}

\section{URSIRACI}

A 4-y-old boy with nephropathic cystinosis and gastrointestinal dysmotility of unknown etiology was treated with i.v. cysteamine over a period of 10 mo. Thirty minutes after a dose of $10 \mathrm{mg} / \mathrm{kg}$ cysteamine free base, the leukocyte cystine value had fallen from 11.9 to $4.9 \mathrm{nmol}$ of half-cystine/mg of protein. When cysteamine was given every $6 \mathrm{~h}$, the leukocyte cystine concentration, measured 5-7 h after a dose, decreased with increasing cysteamine doses up to $17 \mathrm{mg} / \mathrm{kg}$; at this dose the cystine value was $1.1 \mathrm{nmol}$ of half-cystine/mg of protein, or $9 \%$ of the untreated value. Oral administration of approximately 16 $\mathrm{mg} / \mathrm{kg}$ per dose every $6 \mathrm{~h}$ to this patient over the previous $3 \mathrm{y}$ achieved similar leukocyte cystine depletion, to $1.2 \mathrm{nmol}$ of half-cystine/mg of protein. The plasma cysteamine concentration $30 \mathrm{~min}$ after a dose of $10 \mathrm{mg} / \mathrm{kg}$ was $71 \mu \mathrm{M} ; 5-7 \mathrm{~h}$ after a dose of up to $20 \mathrm{mg} / \mathrm{kg}$, the concentration was below $5 \mu \mathrm{M}$. Dimethylsulfide was elevated in the breath and urine of this boy after, but not before, the initiation of i.v. cysteamine therapy. Ten months after the start of therapy, the patient tolerated $250 \mathrm{mg}$ (14 $\mathrm{mg} / \mathrm{kg}$ ) every $8 \mathrm{~h}$. Adverse effects of this treatment included lethargy and increased nausea and vomiting when a schedule of therapy every $6 \mathrm{~h}$ was attempted. This investigation demonstrates that cysteamine given through a central venous catheter is effective in reducing leukocyte cystine levels. (Pediatr Res 38: 579_ 584, 1995)

\section{Abbreviation}

$\mathrm{X}-\mathrm{S}-\mathrm{SCH}_{3}$, the mixed disulfide of an unknown thiol and methyl sulfide
Nephropathic cystinosis is an autosomal recessive disease due to impaired transport of cystine across lysosomal membranes (1-4). The subsequent lysosomal storage of the poorly soluble cystine results in crystal formation and cellular damage in many tissues (5). The earliest involvement occurs in the renal tubules and causes Fanconi syndrome, with polyuria, dehydration, acidosis, rickets, and failure to thrive in infancy $(6,7)$. In untreated cystinosis, the inexorable progression of renal glomerular dysfunction leads to uremia and death by 9-10 y of age, unless dialysis or renal transplantation intervenes $(6,7)$. Cystinosis also results in growth retardation, hypothyroidism, photophobia, retinal damage, posterior synechiae and corneal ulcerations (8), pancreatic exocrine and endocrine insufficiency $(9,10)$, a distal vacuolar myopathy $(11$, 12), swallowing difficulties (13), and CNS involvement (14). These complications occur with variable frequencies and se-

Received January 23, 1995; accepted April 25, 1995.

Correspondence and reprint requests: William A. Gahl, M.D., Ph.D., Building 10 Room 9S-242, NICHD, National Institutes of Health, Bethesda, MD 20892-1830. verities, and at different times in life. However, virtually all posttransplant patients over age 30 suffer some major, debilitating complication of cystinosis (15).

The therapy of nephropathic cystinosis, besides replacement of renal losses, involves treatment with the cystine-depleting agent, cysteamine (16), or its more palatable bioequivalent, phosphocysteamine $(17,18)$. Cysteamine, given orally every 6 $\mathrm{h}$ at a dosage of $1.3-1.95 \mathrm{~g} / \mathrm{m}^{2} /$ day $(60-90 \mathrm{mg}$ of free base/ $\mathrm{kg} /$ day), has proven remarkably efficacious in preventing renal glomerular deterioration (19), permitting improvement of renal function in children under age 3 (20), and enhancing somatic growth in preadolescent cystinosis patients $(19,20)$. Long-term oral cysteamine therapy depletes cystinotic muscle of cystine (21), and topical cysteamine eyedrops dissolve corneal cystine crystals $(22,23)$. These demonstrations of parenchymal organ cystine depletion support a role for cysteamine in treating the nonrenal complications of cystinosis in posttransplant patients. Recently, cysteamine bitartrate capsules (Cystagon, Mylan Pharmaceuticals, Morgantown, WV) were approved by the 
Food and Drug Administration for use in pretransplant cystinosis patients.

Among our patients with nephropathic cystinosis has been a 4-y-old boy who also suffers from gastrointestinal dysmotility refractory to pharmacologic intervention. Because this complication prevented the administration of cysteamine or phosphocysteamine through the gastrointestinal tract, and because a central venous catheter was already in place, we treated this patient with i.v. cysteamine at varying doses. We present data on the subsequent leukocyte cystine depletion as well as the concurrent plasma cysteamine concentrations achieved by this therapy.

\section{METHODS}

Intravenous cysteamine. Cysteamine for i.v. use was prepared by the National Institutes of Health Pharmaceutical Development Service under Investigational New Drug exemption no. 43770 sponsored by W.A.G. Informed consent was obtained from the patient's parents after a protocol was approved by the National Institute of Child Health and Human Development Institutional Review Board. Cysteamine $(50 \mathrm{mg}$ free base $/ \mathrm{mL}$ ) was diluted into a final volume of $50 \mathrm{~mL}$ and administered over 10-20 min into the patient's central venous catheter.

Assays. Leukocyte and tissue cystine concentrations were determined using the cystine binding protein assay (24); protein was measured using the bicinchoninic acid method (25). Plasma cysteamine was assayed by a method developed by Michael Adams and Paul Webster of Mylan Pharmaceuticals; Pharmaco LSR (Richmond, VA) validated and performed the assays. Briefly, plasma cysteamine was extracted with $8 \mathrm{M}$ urea, derivatized with Ellman's reagent [5,5'-dithiobis(2nitrobenzoic acid)], and analyzed by HPLC with UV detection. The minimal quantitation level was $0.100 \mu \mathrm{g} / \mathrm{mL}$; the intraassay coefficient of variability was $5.7 \%$. Breath dimethylsulfide was assayed by gas chromatography as previously described (26). Dimethylsulfide in urine was measured in the same way as previously reported for blood (27). In short, $2 \mathrm{~mL}$ of fresh urine was injected into a closed evacuated $15-\mathrm{mL}$ glass vial. The urine was heated by hot tap water, and the headspace was sampled, concentrated onto Tenax, and investigated by gas chromatography. Methionine transamination metabolites were determined as previously described (28) as the sum of the mixed disulfides $X-\mathrm{S}-\mathrm{SCH}_{3}$ (serum, urine) and protein-S-SCH (serum), and 4-methylthio-2-oxobutyrate (serum, urine).

\section{CASE REPORT}

The patient is a 4-y-old boy who had persistent fetal circulation at birth which required $5 \mathrm{~d}$ of extracorporeal membrane oxygenation for survival. In the first month of life, he fed poorly, required several formula changes, and failed to gain weight appropriately. His development otherwise proceeded normally, despite a prolonged episode of otitis media at age 3 mo and a urinary tract infection at age $8 \mathrm{mo}$. At the time of the urinary tract infection, he was found to have renal tubular Fanconi syndrome and rickets. A leukocyte cystine level of $10.5 \mathrm{nmol}$ of half-cystine per $\mathrm{mg}$ of protein (normal, $<0.2$ ), determined by Dr. Jerry Schneider, University of CaliforniaSan Diego, secured the diagnosis of cystinosis. Corneal cystine crystals were not apparent at this time. Therapy with sodium citrate, phosphate supplements, and dihydrotachysterol was initiated. At 13 mo of age, oral phosphocysteamine therapy was begun and maintained until age $31 / 2$ y at a mean dosage of $1.30 \mathrm{~g} / \mathrm{m}^{2} /$ day $(64 \mathrm{mg}$ of cysteamine free base $/ \mathrm{kg} / \mathrm{day}$ ); this lowered the leukocyte cystine to a mean value of $1.2 \mathrm{nmol}$ of half-cystine/mg of protein.

At 11 mo of age, a gastrostomy tube was placed due to the patient's frequent vomiting and poor feeding; subsequently, his food refusal worsened. A central venous catheter for total parenteral nutrition was placed in the superior vena cava at 14 mo of age and was followed by several episodes of sepsis. Gastrointestinal dysmotility was documented by manometry, but treatment with physostigmine and cisapride proved unsuccessful. Vomiting persisted, especially from midnight to noon, with some relief with ondansetron hydrochloride or metoclopramide. At age $3 y$, an Arnold-Chiari malformation type I was diagnosed and treated with posterior fossa decompression, which resulted in temporary right-sided weakness and cyclic headaches. A karyotype performed at the 550 band level was normal.

On his sixth admission to the National Institutes of Health Clinical Center at age $4 \mathrm{y}$ and $2 \mathrm{mo}$, the patient was able to take liquids, but would chew and spit out solids. Because he vomited several times a day and could not tolerate oral medications, phosphocysteamine had been discontinued approximately 6 mo before this admission. Nutrition was provided by total parenteral nutrition $(2180 \mathrm{~mL} /$ day $)$, although a jejunostomy tube was placed for some medications. On physical examination, the patient was a normal appearing, active blonde boy with a Hickman catheter in place. Height was $97.8 \mathrm{~cm}(5-10$ centile), weight $15.1 \mathrm{~kg}(10-25$ centile), and head circumference $51.5 \mathrm{~cm}$ (50-75 centile). The remainder of the examination was unremarkable. Serum sodium was $138 \mathrm{mEq} / \mathrm{L}$, potassium $3.4 \mathrm{mEq} / \mathrm{L}$, chloride $104 \mathrm{mEq} / \mathrm{L}$, and carbon dioxide 28 $\mathrm{mEq} / \mathrm{L}$. Serum creatinine was $1.1 \mathrm{mg} / \mathrm{dL}$, blood urea nitrogen $7 \mathrm{mg} / \mathrm{dL}$, alkaline phosphatase $230 \mathrm{U} / \mathrm{L}$, alanine aminotransferase $14 \mathrm{U} / \mathrm{L}$, aspartate aminotransferase $41 \mathrm{U} / \mathrm{L}$, albumin 4.4 $\mathrm{g} / \mathrm{dL}$, calcium $2.59 \mathrm{mmol} / \mathrm{L}$, magnesium $0.83 \mathrm{mmol} / \mathrm{L}$, and thyroxine $11.7 \mu \mathrm{g} / \mathrm{dL}$. The $\mathrm{Hb}$ was $7.4 \mathrm{~g} / \mathrm{dL}$, hematocrit $20.1 \%$, and platelet count $95,000 / \mathrm{mm}^{3}$. The white blood cell count was $2500 / \mathrm{mm}^{3}$, with $43 \%$ polymorphonuclear cells, $44 \%$ lymphocytes, $6 \%$ mononuclear cells, $6 \%$ eosinophils, and $1 \%$ basophils. The reticulocyte count was $2 \%$. The erythropoietin level was $5 \mathrm{mU} / \mathrm{mL}$, inappropriately low for the patient's degree of anemia. A bone marrow biopsy and aspirate revealed a myeloid/erythroid ratio of $1.3 / 1$ with diffuse lymphocytosis and focal eosinophilia, mild megaloblastic granulopoiesis, and crystal-laden macrophages. Two creatinine clearance measurements were low, i.e. 27 and $48 \mathrm{~mL} / \mathrm{min} / 1.73 \mathrm{~m}^{2}$.

At $4 \% 12$ y of age, manometry was performed by one of us (P.E.H.). Fasting and postprandial antroduodenal manometry was dominated by normal amplitude propagating and nonpropagating clustered contractions, a pattern of repetitive discreet abnormalities typical of a neuropathic intestinal motility disorder. Colonic manometry was normal. 


\section{RESULTS}

Gastrointestinal biopsies. A rectal biopsy performed at 3 y and 4 mo revealed typical cystine crystals within fibroblasts and histiocytes of the lamina propria (Fig. 1). In addition, noncrystalline deposits and membranous whorls were evident. The biopsy contained $3.0 \mathrm{nmol}$ of half-cystine/mg of protein (normal large intestine (Brain and Tissue Bank, University of Miami), $0.064 \pm 0.036 \mathrm{SEM}$ nmol of half-cystine/mg of protein, $n=3$ ). Subsequently, at $4 \mathrm{y}$ of age, biopsies of the esophageal, gastric, duodenal, and rectal mucosa were also performed. Crystals were apparent on light and electron microscopy within the macrophages of the lamina propria in the duodenum (Fig. 2). No other specific pathology was observed. Ganglion cells were present in the rectal biopsy. The rectal mucosa contained $0.37 \mathrm{nmol}$ of half-cystine/mg of protein and the submucosa contained $0.23 \mathrm{nmol}$ of half-cystine $/ \mathrm{mg}$ of protein.

Intravenous cysteamine. Intravenous cysteamine was initiated at age 4 y and 2 mo because of inability to tolerate enteral cysteamine. The patient received increasing doses of cysteamine through his central line, each given in $50 \mathrm{~mL}$ of normal saline over approximately $20 \mathrm{~min}$. At 5 or $10 \mathrm{mg} / \mathrm{kg}$ per dose ( 75 or $150 \mathrm{mg}$ of free base), i.v. cysteamine lowered leukocyte cystine values (baseline, $11.9 \mathrm{nmol}$ of half-cystine/mg of protein) approximately $50 \%$ within $30 \mathrm{~min}$ and maintained this depletion for up to $6 \mathrm{~h}$ (Fig. 3). In fact, leukocyte cystine concentrations $5-7 \mathrm{~h}$ after a dose of cysteamine fell progressively with increasing doses of the drug (up to $17 \mathrm{mg} / \mathrm{kg}$ ), leveling off at $1.1 \mathrm{nmol}$ of half-cystine/mg of protein, or $9 \%$ of baseline (Fig. 4).

Peak plasma cysteamine levels after doses of 5 or $10 \mathrm{mg} / \mathrm{kg}$ were observed $30 \mathrm{~min}$ after a cysteamine injection, and reached 35 and $71 \mu \mathrm{M}$, respectively (Fig. 3). The half-times for loss of cysteamine from the plasma, based upon the 30- and 90-min values, were $18 \mathrm{~min}$ for the $5 \mathrm{mg} / \mathrm{kg}$ dose and $20 \mathrm{~min}$ for the $10 \mathrm{mg} / \mathrm{kg}$ dose. Five to seven hours after a cysteamine dose of $5 \mathrm{mg} / \mathrm{kg}$, plasma cysteamine was undetectable $(<1.3 \mu \mathrm{M})$.

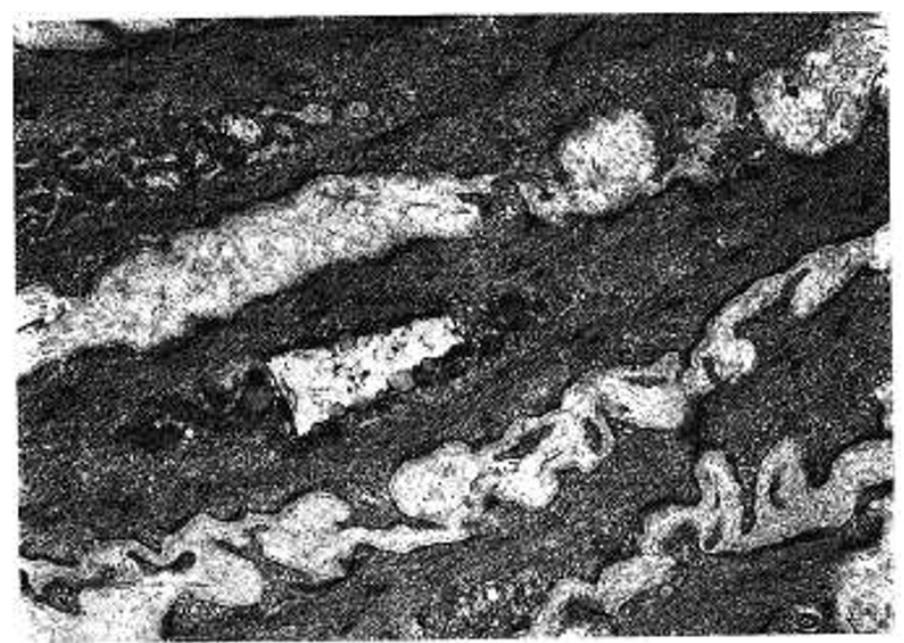

Figure 1. Electron micrograph of rectal biopsy at $34 / 12 \mathrm{y}$ of age. (Courtesy of Dr. James Southern, Department of Pathology, Massachusetts General Hospital.) Crystal surrounded by vacuoles storing amorphous noncrystalline material $(\times 9100)$.

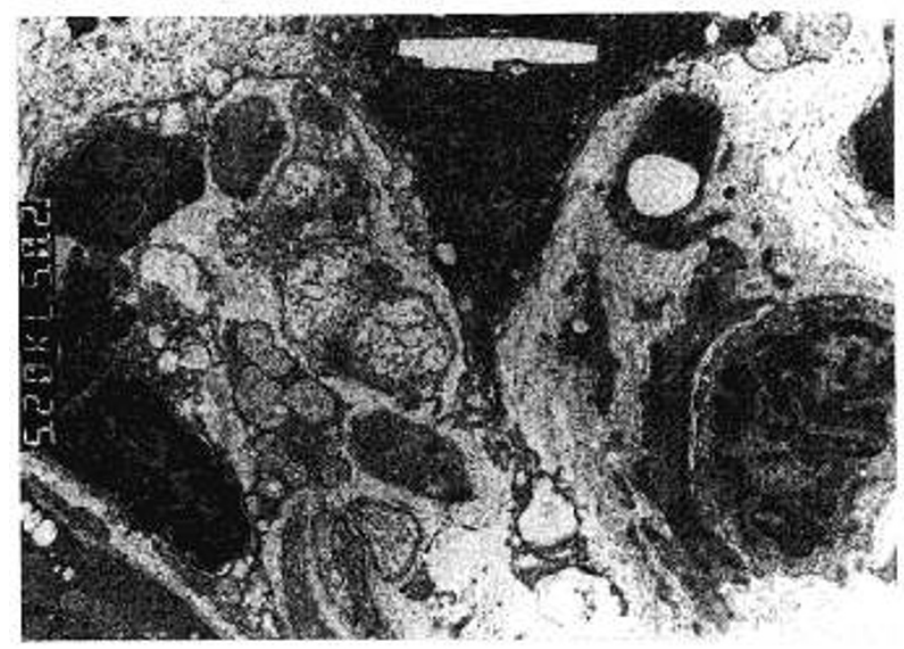

Figure 2. Electron micrograph of duodenal biopsy performed at $4 \mathrm{y}$ of age. (Courtesy of Dr. Dena M. Selby, Attending Pathologist, Children's National Medical Center.) A macrophage in the lamina propria shows a single intracytoplasmic cystine crystal $(\times 5200)$.

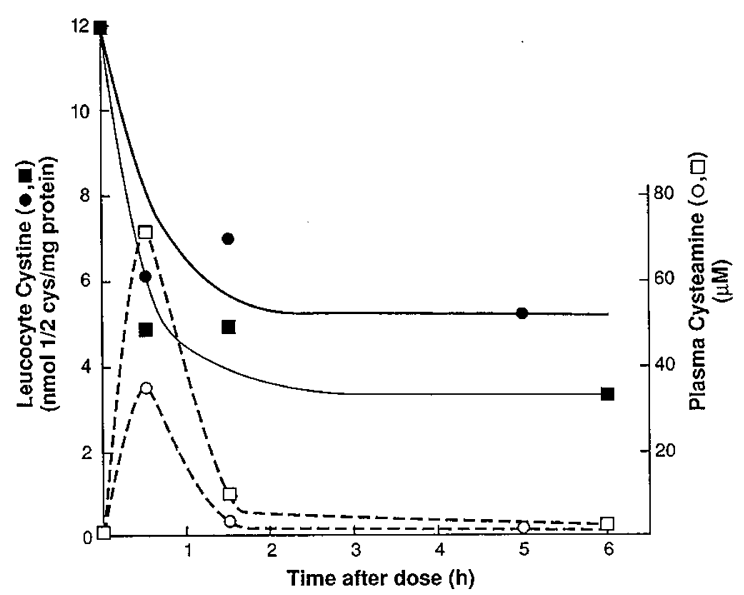

Figure 3. Leukocyte cystine levels and plasma cysteamine concentrations after i.v. doses of cysteamine. A single dose of $5 \mathrm{mg} / \mathrm{kg}(75 \mathrm{mg}$ of cysteaminefree base, $\bigcirc, 0)$ or $10 \mathrm{mg} / \mathrm{kg}(150 \mathrm{mg}$ of cysteamine-free base, $\square, \square)$ was injected into the patient's central line in a volume of $50 \mathrm{~mL}$ of normal saline over $20 \mathrm{~min}$, and blood was sampled after various times. Single leukocyte cystine determinations are represented by filled symbols; plasma cysteamine values are open symbols. The lower limit of detection for plasma cysteamine is $1.3 \mu \mathrm{M}$.

However, doses of $10-20 \mathrm{mg} / \mathrm{kg}$ yielded increasing plasma cysteamine concentrations $5-7 \mathrm{~h}$ later, ranging from $1.9 \mu \mathrm{M}$ for $10 \mathrm{mg} / \mathrm{kg}$ to $4.1 \mu \mathrm{M}$ for $20 \mathrm{mg} / \mathrm{kg}$ (Fig. 4). (Note the 20 -fold increased scale in Fig. 4 compared with that in Fig. 3.)

Dimethylsulfide in both breath $(<0.1 \mathrm{nmol} / \mathrm{L})$ and urine $(<5$ $\mathrm{nmol} / \mathrm{L})$ were undetectable in the patient before cysteamine therapy. However, after the patient received $60-68 \mathrm{mg} / \mathrm{kg} / \mathrm{day}$ of i.v. cysteamine for $9 \mathrm{~d}$, breath dimethylsulfide was 8.35 $\mathrm{nmol} / \mathrm{L}$ and urine dimethylsulfide, $500 \mathrm{nmol} / \mathrm{L}$. Dimethyldisulfide, $0.5 \mathrm{nmol} / \mathrm{L}$ (normal, zero), was also detected in the breath after i.v. cysteamine therapy. However, the methionine transamination metabolites (mixed disulfides and $\mathrm{X}-\mathrm{S}-\mathrm{SCH}_{3}$, protein-S- $\mathrm{SCH}_{3}$, and 4-methylthio-2-oxobutyrate) remained normal in both urine (before cysteamine, $0.51 \mathrm{mmol} / \mathrm{mol} \mathrm{cre}-$ atinine; after, $2.37 \mathrm{mmol} / \mathrm{mol}$ creatinine; normal, $0.7-3.2$ $\mathrm{mmol} / \mathrm{mol}$ creatinine) and serum (before cysteamine, 0.31 


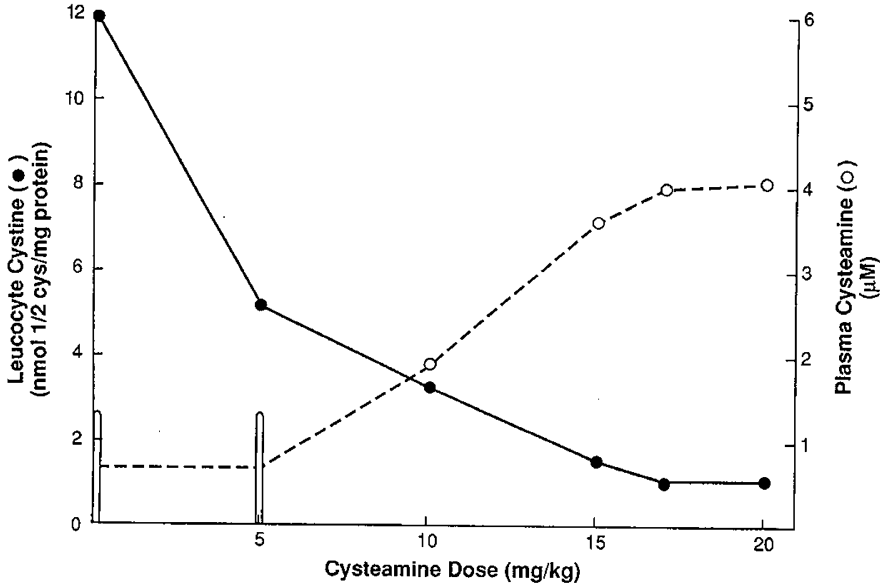

Figure 4. Leukocyte cystine $(\bigcirc)$ and plasma cysteamine $(\bigcirc)$ concentrations after various doses of i.v. cysteamine. In all cases, blood was drawn 5-7 h after the dose of cysteamine, i.e. at the nadir for plasma cysteamine and just before the next dose. After doses of 0 or $5 \mathrm{mg} / \mathrm{kg}$, the plasma cysteamine concentration was below the assay's detection limit $(1.3 \mu \mathrm{M})$, as signified by the open bars. Symbols represent single determinations.

$\mu \mathrm{mol} / \mathrm{L}$; after, $0.47 \mu \mathrm{mol} / \mathrm{L}$; normal, $0.20-0.50 \mu \mathrm{mol} / \mathrm{L})$. The patient emitted a sulfur-like breath odor similar to the odor he had previously displayed on oral cysteamine.

Long-term therapy. Intravenous cysteamine therapy was continued at home at doses of $12-14 \mathrm{mg} / \mathrm{kg}$ every $6 \mathrm{~h}$. After 3 mo, the mean leukocyte cystine value was $1.4 \mathrm{nmol}$ of halfcystine/mg of protein and the mean plasma cysteamine was 2.5 $\mu \mathrm{M} 5-7 \mathrm{~h}$ after a dose. After $8 \mathrm{mo}$, the mean leukocyte cystine value was $2.0 \mathrm{nmol}$ of half-cystine $/ \mathrm{mg}$ of protein. However, in general, therapy could be given only every $8 \mathrm{~h}$ owing to nausea, vomiting, and lethargy which became nearly constant when i.v. cysteamine was given at 6 -h intervals. Ten months after the initiation of i.v. cysteamine, the patient was able to tolerate $250 \mathrm{mg}(14 \mathrm{mg} / \mathrm{kg})$ every $8 \mathrm{~h}$ with vomiting approximately three times per day. In addition, the patient was able to take $50 \%$ of his calories by jejunostomy tube while on scheduled ondansetron hydrochloride, $4 \mathrm{mg}$ t.i.d.

The mean creatinine clearance in the 2 y before i.v. cysteamine therapy was $37.1 \pm 9.5 \mathrm{~mL} / \mathrm{min} / 1.73 \mathrm{~m}^{2}(n=8)$; the mean creatinine clearance in the $8 \mathrm{mo}$ after i.v. cysteamine therapy was $34.5 \pm 8.7 \mathrm{~mL} / \mathrm{min} / 1.73 \mathrm{~m}^{2}(n=4)$.

\section{DISCUSSION}

Various types of gastrointestinal involvement have been recognized in nephropathic cystinosis, including ulcerative colitis in a single patient (29) and cystine accumulation in several affected children $(30,31)$. In these individuals, cystine crystals were demonstrated within histiocytes of the rectal lamina propria, corresponding to the location of crystals in our patient's rectal mucosa. Intestinal cystine concentrations in cystinosis patients have not been previously reported, but our patient's values were clearly elevated at $3 \mathrm{nmol}$ of half-cystine per mg of protein. On the other hand, this boy's rectal mucosal cystine concentration was considerably less than that of another 6-y-old cystinosis patient (182 nmol of half-cystine/mg of protein) (Gahl W, unpublished data), who had normal gastrointestinal motility. Consequently, we cannot attribute our patient's gastrointestinal dysmotility to cystine accumulation or to any aspect of his cystinosis. Although many children with cystinosis have nausea and vomiting, none has had the severe, intractable problems experienced by our patient. Additionally, Arnold-Chiari malformation and persistent fetal circulation complicated his history and suggest other etiologies for the unusual course of his disease. We also cannot blame cysteamine therapy itself; although cysteamine is a duodenal ulcerogen in rats (32), we know of no reports of gastrointestinal dysmotility resulting from the therapy. In fact, the patient's dysmotility preceded the initiation of cysteamine therapy.

Whatever the cause, this boy's gastrointestinal dysfunction in the face of cystinosis called for administration of parenteral cysteamine. To our knowledge, there has been only one other report involving the use of i.v. cysteamine (16). A single i.v. dose of $10 \mathrm{mg} / \mathrm{kg}$ was administered to a 7 -y-old girl over a 5-min period; $1 \mathrm{~h}$ later, the leukocyte cystine concentration was $30 \%$ of the initial value. Plasma cysteamine determinations were not available.

Our patient underwent incremental dosing of i.v. cysteamine to a maximum of $20 \mathrm{mg} / \mathrm{kg}$ per dose, with leukocyte cystine levels decreasing as the dose was increased (Fig. 4). Moreover, the response of the leukocyte cystine concentration to i.v. cysteamine resembled that typical for oral cysteamine. For example, we noted a $62 \%$ leukocyte cystine depletion $90 \mathrm{~min}$ after an i.v. cysteamine dose of $10 \mathrm{mg} / \mathrm{kg}$; Smolin et al. (18) found $62 \%$ depletion $1 \mathrm{~h}$ after a dose of $18 \mathrm{mg} / \mathrm{kg}$. With our patient serving as his own control, leukocyte cystine concentrations at their nadir (approximately $6 \mathrm{~h}$ after a dose) were virtually identical whether the dose was received i.v. or orally. Specifically, when $68 \mathrm{mg} / \mathrm{kg} /$ day was given i.v., the leukocyte cystine was $1.1 \mathrm{nmol}$ of half-cystine/mg of protein and when $64 \mathrm{mg} / \mathrm{kg} /$ day was given orally, the value was $1.2 \mathrm{nmol}$ of half-cystine/mg of protein. This suggests virtually complete gastrointestinal absorption of cysteamine.

This observation finds further support in comparison of peak plasma cysteamine concentrations after i.v. and oral doses of cysteamine. Smolin et al. (18) administered $0.23 \mathrm{mmol} / \mathrm{kg}$ (18 $\mathrm{mg} / \mathrm{kg}$ ) of cysteamine orally to six children with cystinosis age 2-10 y and reported peak plasma cysteamine concentrations of 34.1-62.7 $\mu \mathrm{M}$ (mean $\pm \mathrm{SD}, 48.6 \pm 10.7 \mu \mathrm{M}$ ) 30-60 min later. (Oral phosphocysteamine gave virtually the same results as cysteamine itself.) Jonas and Schneider (33) administered $0.14-0.23 \mathrm{mmol} / \mathrm{kg}(11-18 \mathrm{mg} / \mathrm{kg})$ per dose to five cystinosis patients age 1-9 y and reported plasma cysteamine concentrations of 14-54 $\mu \mathrm{M} 1 \mathrm{~h}$ later. Our patient's plasma cysteamine concentration $30 \mathrm{~min}$ after an i.v. dose of $10 \mathrm{mg} / \mathrm{kg}$ was 71 $\mu \mathrm{M}$. In Jonas and Schneider's study, plasma cysteamine concentrations ranged from undetectable $(<5 \mu \mathrm{M})$ to $18 \mu \mathrm{M} 6 \mathrm{~h}$ after a dose; in our patient, the plasma cysteamine averaged 3.6 $\mu \mathrm{M} 5-7 \mathrm{~h}$ after a dose of $15 \mathrm{mg} / \mathrm{kg}$.

The relatively short half-life of cysteamine in plasma, approximately $20 \mathrm{~min}$, reflects its conversion to excretable sulfurcontaining compounds. Jonas and Schneider (33) have reported only $0.3-1.7 \%$ of an oral dosage of $6.6-15.8 \mathrm{mmol} /$ day excreted intact in the urine, indicating that other metabolites must be involved. One such product is dimethylsulfide, a volatile 
compound that was also highly elevated in a breath sample taken $9 \mathrm{~d}$ after the initiation of cysteamine therapy. Dimethylsulfide did not make a significant contribution to the patient's urinary sulfur excretion, because it amounted to less than 1 $\mu \mathrm{mol} /$ day. However, its expiration via this patient's breath $(8.35 \mathrm{nmol} / \mathrm{L})$ would approximate $0.3 \mathrm{mmol}$ daily. This amounts of $3.1 \%$ of the total cysteamine dose (approximately $9.7 \mathrm{mmol} / \mathrm{day})$. The contribution of the proposed pathway might be much higher than 3.1\%, however, because a large portion may have escaped detection via other metabolites of methanethiol, e.g. sulfate (34).

More important, the presence of dimethylsulfide in our patient's breath and urine may indicate a new pathway in cysteamine catabolism. To our knowledge, dimethylsulfide has not previously been identified as a metabolite of cysteamine. We propose that cysteamine is first methylated to the thioether (35), followed by a cytochrome P-450-mediated $S$-dealkylation of the thioether to methanethiol (36) and a second methylation to dimethylsulfide (Fig. 5). That methanethiol is an intermediate is supported by the presence of small amounts of dimethyldisulfide, the oxidation product of methanethiol, in the patient's breath. The breakdown of cysteamine to dimethylsulfide and dimethyldisulfide must be of mammalian origin and could not have occurred due to a chemical breakdown of cysteamine before its infusion because neither dimethylsulfide, dimethyldisulfide, nor methanethiol was present in the cysteamine solution before infusion. The proposed pathway of dimethylsulfide formation would not have been attributed to human metabolism if the cysteamine had been administered orally, because gut organisms would have been blamed for the products formed.

The main adverse effect of i.v. cysteamine observed in this study was an increased frequency of vomiting and the occurrence of lethargy at high doses, typical of oral cysteamine. The fact that vomiting was exacerbated by i.v. cysteamine indicates that its emetic effects are not entirely due to its putrid smell and repulsive taste, nor due to direct gastrointestinal upset. Rather, cysteamine appears to be acting centrally, eliciting an emetic response at high plasma concentrations. This is consistent with the occasional somnolence and lethargy observed with high doses of oral cysteamine (37). An additional nuisance associated with i.v. or oral cysteamine is an offensive breath odor, here attributable to dimethylsulfide. A similar finding has been reported in a 31-y-old man with methionine adenosyltransferase deficiency (38).

The pharmacokinetic findings in our patient may not be directly applicable to other children or adults with cystinosis.

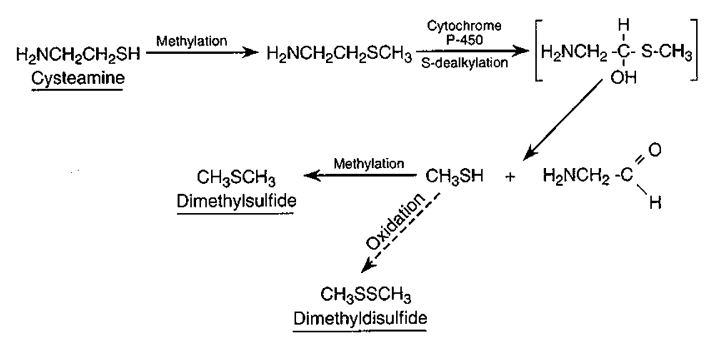

Figure 5. Proposed scheme of dimethylsulfide synthesis from cysteamine.
In addition, i.v. cysteamine therapy should be reserved for the rare or, perhaps, unique case in which gastrointestinal dysmotility prevents the alimentary tract from providing access for nutrition and medication. Ordinarily, a child with cystinosis who vomits excessively and does not tolerate oral cysteamine can still be nourished and treated through a gastrostomy or jejunostomy tube.

Cysteamine is now approved for use only in pretransplant cystinosis patients, although its use in posttransplant patients has been proposed to prevent late complications of the disease $(8-15,21)$. Nevertheless, the theoretical applications of cysteamine are quite extensive. Whenever an arginine to cysteine substitution occurs in a circulating protein, cysteamine has the potential to convert the cysteine back to an arginine or lysine analog by forming the mixed disulfide cysteine-cysteamine. Examples include apolipoprotein $\mathrm{E}_{2}$ (39) and anti-thrombin III $_{\text {Toyama }}(40)$. Another possible therapeutic use of cysteamine is in human immunodeficiency virus infections, because cystamine, the disulfide of cysteamine, has recently been shown to inhibit human immunodeficiency virus replication in a cell culture system (41).

\section{REFERENCES}

1. Gahl WA, Bashan N, Tietze F, Bernardini I, Schulman JD 1982 Cystine transport is defective in isolated leukocyte lysosomes from patients with cystinosis. Science 217:1263-1265

2. Gahl WA, Tietze F, Bashan N, Steinherz R, Schulman JD 1982 Defective cystine exodus from isolated lysosome-rich fractions of cystinotic leucocytes. J Biol Chem 257:9570-9575

3. Jonas AJ, Smith ML, Schneider JA 1982 ATP-dependent lysosomal cystine efflux is defective in cystinosis. J Biol Chem 257:13185-13188

4. Gahl WA, Tietze F, Bashan N, Bernardini I, Schulman JD 1983 Characteristics of cystine counter-transport in normal and cystinotic lysosome-rich leucocyte granular fractions. Biochem J 216:393-400

5. Gahl WA, Schneider JA, Aula P 1995 Lysosomal transport disorders: cystinosis and sialic acid storage disorders. In: Scriver CR, Beaudet AL, Sly WS, Valle D (eds) The Metabolic Basis of Inherited Disease, 7th Ed. McGraw-Hill, New York, pp 37633797

6. Krasnewich D, Gahl WA 1991 Cystinosis: a treatable lysosomal storage disease. Endocrinologist 1:111-118

7. Gahl WA 1986 Cystinosis coming of age. Adv Pediatr 33:95-126

8. Kaiser-Kupfer MI, Caruso RC, Minckler DS, Gahl WA 1986 Long-term ocular manifestations in nephropathic cystinosis post-renal transplantation. Arch Ophthalmol 104:706-711

9. Fivush B, Flick JA, Gahl WA 1988 Pancreatic exocrine insufficiency in a patient with nephropathic cystinosis. J Pediatr 112:49-51

10. Fivush B, Green OC, Porter CC, Balfe JW, O'Regan S, Gahl WA 1987 Pancreatic endocrine insufficiency in post-transplant cystinosis. Am J Dis Child 141:1087-1089

11. Gahl WA, Dalakas MC, Charnas L, Chen KTK, Pezeshkpour GH, Kuwabara T, Davis SL, Chesney RW, Fink J, Hutchison HT 1988 Myopathy and cystine storage in muscles in a patient with nephropathic cystinosis. N Engl J Med 319:1461-1464

12. Charnas LR, Luciano CA, Dalakas M, Gilliatt RW, Bernardini I, Ishak K, Cwik VA, Fraker D, Brushart TA, Gahl WA 1994 Distal vacuolar myopathy in nephropathic cystinosis. Ann Neurol 35:181-188

13. Sonies BC, Ekman EF, Andersson HC, Adamson M, Kaler S, Markello T, Gahl WA 1990 Swallowing dysfunction in nephropathic cystinosis. N Engl J Med 323:565-570

14. Fink JK, Brouwers P, Barton N, Malekzadeh MH, Sato S, Hill S, Cohen WE, Fivush B, Gahl WA 1989 Neurologic complications in longstanding nephropathic cystinosis. Arch Neurol 46:543-548

15. Theodoropoulos DS, Krasnewich D, Kaiser-Kupfer MI, Gahl WA 1993 Classic nephropathic cystinosis as an adult disease. JAMA 270:2200-2204

16. Thoene JG, Oshima RG, Crawhall JC, Olson DL, Schneider JA 1976 Cystinosis: Intracellular cystine depletion by aminothiols in vitro and in vivo. $\mathrm{J}$ Clin Invest 58:180-189

17. Thoene JG, Lemons R 1980 Cystine depletion of cystinotic tissues by phosphocysteamine (WR638). J Pediatr 96:1043-1044

18. Smolin LA, Clark KF, Thoene JG, Gahl WA, Schneider JA 1988 A comparison of the effectiveness of cysteamine and phosphocysteamine in elevating plasma cysteamine concentration and decreasing leukocyte free cysitne in nephropathic cystinosis. Pediatr Res 23:616-620

19. Gahl WA, Reed GF, Thoene JG, Schulman JD, Rizzo WB, Jonas AJ, Denman DW, Schlesselman JJ, Corden BJ, Schneider JA 1987 Cysteamine therapy for children with nephropathic cystinosis. N Engl J Med 316:971-977 
20. Markello TC, Bernardini IM, Gahl WA 1993 Improved renal function in children with cystinosis treated with cysteamine. N Engl J Med 328:1157-1162

21. Gahl WA, Charnas L, Markello T, Bernardini I, Ishak KG, Dalakas M 1992 Parenchymal organ cystine depletion with long-term cysteamine therapy. Biochem Med Metab Biol 48:275-285

22. Kaiser-Kupfer MI, Fujikawa L, Kuwabara T, Gahl WA 1987 Removal of corneal crystals by topical cysteamine in nephropathic cystinosis. N Engl J Med 316:775-779

23. Kaiser-Kupfer MI, Gazzo MA, Datiles MB, Caruso RC, Kuehl EM, Gahl WA 1990 A randomized placebo-controlled trial of cysteamine eyedrops in nephropathic cystinosis. Arch Ophthalmol 1089:689-693

24. Oshima RG, Willis RC, Furlong CE, Schneider JA 1974 Binding assays for amino acids. The utilization of a cystine binding protein from Escherichia coli for the determination of acid-soluble cystine in small physiological samples. J Biol Chem 249:6033-6039

25. Smith PK, Krohn RI, Hermanson GT, Mallia AK, Gartner FH, Provenzano MD, Fujimoto EK, Goeke NM, Olson BJ, Klenk DC 1985 Measurement of protein using bicinchoninic acid. Anal Biochem 150:76-85

26. Tangerman A, Meuwese-Arends MT, van Tongeren JHM 1983 A new sensitive assay for measuring volatile sulphur compounds in human breath by Tenax trapping and gas chromatography and its application in liver cirrhosis. Clin Chim Acta 130:103-110

27. Tangerman A, Meuwese-Arends MT, van Tongeren JHM 1985 New methods for the release of volatile sulfur compounds from human serum: its determination by Tenax trapping and gas chromatography and its application in liver diseases. J Lab Clin Med 106:175-182

28. Blom HJ, Boers GHJ, van den Elzen JPAM, Gahl WA, Tangerman A 1989 Transamination of methionine in humans. Clin Sci 76:43-49

29. Treem WR, Rusnack EJ, Ragsdale BD, Seikaly MG, DiPalma JS 1988 Inflammatory bowel disease in a patient with nephropathic cystinosis. Pediatrics 81:584-587

30. Holtzapple PG, Genel M, Yakovac WC, Hummeler K, Segal S 1969 Diagnosis of cystinosis by rectal biopsy. N Engl J Med 281:143-145
31. Morecki R, Paunier L, Hamilton JR 1968 Intestinal mucosa in cystinosis. A fine structure study. Arch Pathol 86:297-307

32. Robert A, Nezamis JE, Lancaster C, Badalamenti JN 1974 Cysteamine-induced duodenal ulcers: a new model to test antiulcer agents. Digestion 11:199-214

33. Jonas AJ, Schneider JA 1982 Plasma cysteamine concentrations in children treated for cystinosis. J Pediatr 100:321-323

34. Blom HJ, Tangerman A 1988 Methanethiol metabolism in whole blood. J Lab Clin Med 111:606-610

35. Mannervik B 1982 Mercaptans. In: Jakoby WB, Bend JR, Caldwell J (eds) Metabolic Basis of Detoxification. Academic Press, New York, pp 185-206

36. Wolf CR 1982 Oxidation of foreign compounds at carbon atoms. In: Jakoby WB, Bend JR, Caldwell J (eds) Metabolic Basis of Detoxification. Academic Press, New York, pp 5-28

37. Corden BJ, Schulman JD, Schneider JA, Thoene JG 1981 Adverse reactions to oral cysteamine use in nephropathic cystinosis. Dev Pharmacol Ther 3:25-30

38. Gahl WA, Bernardini I, Finkelstein JD, Tangerman A, Martin JJ, Blom HJ, Mullen $\mathrm{KD}$, Mudd SH 1988 Transsulfuration in an adult with hepatic methionine adenosyltransferase deficiency. J Clin Invest 81:390-397

39. Fisher EA, Gahl WA 1982 Cysteamine in treatment of type III hyperlipidaemia? Lancet 1:1131-1132

40. Koide T, Odani S, Takahashi K, Ono T, Sakuragawa N 1984 Antithrombin III Toyama: replacement of arginine -47 by cysteine in hereditary abnormal antithrombin III that lacks heparin-binding ability. Proc Natl Acad Sci USA 81:289-293

41. Bergamini A, Capozzi M, Ghibelli L, Dini L, Salanitro A, Milanese G, Wagner T, Beninati S, Pesce CD, Amici C, Rocchi G 1994 Cystamine potently suppresses in vitro HIV replication in acutely and chronically infected human cells. J Clin Invest 93:2251-2257 